\title{
THE ARBITRATION OF LABOR DISPUTES
}

\section{E. L. Oliver $\dagger$}

Reappearance of open industrial warfare on a large scale, in 1933 and $1934,{ }^{1}$ has forced upon the attention of industrial and political leaders the problem of finding some method for securing amicable adjustment of labor disputes. Dramatic local strikes, culminating in the San Francisco general strike, have been followed by threats of nation-wide strikes in various industries. The textile walk-out, covering perhaps the largest area of any strike in our industrial history (with the exception of national railway strikes), is an indication of what may easily happen in the steel, automobile, and other of our great industries. It is true that we have had periods of violent labor conflict before, but there has never been a time when the symptoms and vigorous expression of industrial unrest have been so general and so serious. What happened in Toledo and Minneapolis may be happening tomorrow in any one of our cities.

It would be a serious mistake, however, to gauge the nature or extent of the labor conflict, or to base any public policy with reference to labor disputes, solely upon strikes or lockouts. In fact, the strike bears about the same relationship to the labor problem as war does to international trade. Almost every contact between employer and employee has in it some element of controversy. Questions of wages, hours, and working conditions are being settled daily in every union and non-union establishment in the country. Individual or collective employment contracts are being made or changed continually; workers are being hired, furloughed, or dismissed. Men are being promoted, demoted, and disciplined by their employers, and are protesting when they consider themselves unjustly treated. It is only when a substantial group of workers act concertedly in such a protest, and when no settlement satisfactory to both employer and employee groups is reached, that the strike or lockout results.

Strike prevention, consequently, is not the only-nor the primarypublic concern in labor controversies. Employers may be satisfied with a policy which would forestall collective action by employees, or break strikes when they cannot be prevented. The community interest is much broader and much more fundamental than this. Entirely apart from questions of abstract justice to the parties directly involved, labor disputes must be considered in the light of their complex effect upon the welfare of the entire community. Any method of settling such disputes must be judged by its

$\div$ A. B., I9I8, University of Minnesota; Director of the Research Department, Brotherhood of Railway Clerks.

r. Strikes and lockouts reported by the Bureau of Labor Statistics caused loss of $2,730,000$ man-days in 1930 , and 13,455 ,000 man-days in I933. Time lost in the first four months of I934 was more than four times as great as in the same period of I933. 38 MoNTHLY LABOR Rev. (U. S. Dept. of Labor, I934) 1377. 
total effect; simple repression or a policy of preventing strikes at all costs will not meet the situation.

Contrary as it may be to the general opinion, the "public" is much more concerned in the outcome of labor disputes than it is in the means by which the disputes are conducted. An individual strike or lockout may cause public inconvenience, even hardship, but in the long run and over the whole labor field the terms upon which controversies are settled have an incomparably greater effect than the local and temporary dislocations of the period of open conflict. Wage and production losses during stoppages are negligible compared with the wages paid and the industrial output during the life of collective labor agreements. ${ }^{2}$ The working and living conditions of millions of people are governed directly by union agreements; and conditions in nonunion establishments, though less favorable to the employees, are largely determined by what union labor has secured. The income of every other group in the community, and general business conditions, are but little less directly affected. The great bulk of our urban population is in some way concerned in the terms upon which labor disputes are settled. Public policy in handling labor disputes, therefore, should be directed not only toward strike prevention, but also toward the making of sound and equitable settlements of the issues involved.

Before attempting an assay of arbitration as a means of settling labor disputes, it will perhaps be well to consider the types of disputes normally arising in industry, and the general methods of disposing of them.

\section{Types of Labor Controversies}

Labor disputes usually involve one or both of two types of issues. For a proper understanding of these issues, one must look at their origins-at the establishment in which there is no labor organization, and no apparent labor dispute. In the typical plant of this class, the employer of the pre-depression era hired, fired, promoted, demoted, disciplined and rewarded whom he chose. The number of workers, their wages, hours and working conditions, their age, sex, nationality, and physical qualifications, their principles-even their religion or politics-were his to determine in dealing with his personnel. If industrial conditions or other considerations induced him to bargain, he dealt with the individual employee. Dissatisfaction in such an establishment was ordinarily expressed only very cautiously, because each employee knew the imminent danger of discharge. The employer usually thought and said that his employees were satisfied, when as a matter of fact they were more often simply frightened into silence. When low wages, long hours, or other working conditions did bring expressions of protest, the individual employee

2. Assuming an average of 2,000,000 people working under union agreements in 1933, the man-days worked would have totalled six hundred million, the time lost in strikes, thirteen and a half million. 
learned to talk only to those whom he could trust, and to get a group interested before any action was taken. Advice and help were often, but not always, sought from or offered by already organized workers. Such a movement might be started because of a desire to raise wages or shorten hours; when the employer learned of it, his standard reaction was to discharge the "agitators" or "ringleaders". At that point, the movement for increasing wages was usually subordinated, and the employees instead demanded the reinstatement of the men discharged. The employer frequently refused to meet with the committee or other representatives of his employees, and the employees from then on also asked for the right to speak through union representatives in conference with the employer. Reinstatement of the workers discharged meant simply "recognition of the right to organize". Neeting with the committee representing the employees meant "recognition of the union". These two demands, it will be seen, are quite different from the original demand for wage increases or shortening of hours; the one type of demand is for specific changes in employment conditions, the second is for a limitation of the absolute power of the employer.

Disputes thus arise out of demands for increased wages, shortened hours, payment for overtime, fixed starting or quitting times, proper lighting or sanitary conditions; but they also arise out of demands for the right to organize, union recognition, union participation in dismissals or discipline, regulation of promotion and demotion, elimination of discrimination against women, etc. Union progress, where collective action has been successful, has consisted not only in the shortening of hours and raising of wages, but also in the steady limitation of the power of the employer over the employees. These two primary types of issues in labor disputes must be kept in mind in considering the whole problem of peaceful adjustment of employer-employee relationships. ${ }^{3}$

In addition to this classification upon the basis of the issues involved, labor disputes should also be considered from the standpoint of the form in which they arise. Where labor is organized, wages and working conditions are ordinarily fixed by definite agreements. Disputes may arise, in the first place, in making or modifying these basic agreements; they may arise, also, in the interpretation or application of the agreements in specific situations.

Wage and rules agreements usually have either a definite termination date, or a provision that they may be terminated by either party upon stipulated notice. Proposals to change basic agreements, ordinarily, must be made in advance of the termination date or in accordance with whatever notice is provided for termination. ${ }^{4}$ Disputes arising out of such proposals are thus

3. For an instructive analogy between the development of political democracy and the extension of collective bargaining see Leiserson, Constitutional Govermment in American Industries (March I922) 12 Am. Econ. Rev.; March Supp. 56.

4. At least 30 days' notice must be given of intended changes in wages, rules, or working conditions of railway workers. RAILWAy LABOR ACT, 44 STAT. 582, §6 (I926), 45 U. S. C. A. $\S 156$ (Supp. 1933). 
definite and formal; they generally involve matters of considerable importance to the entire group.

On the other hand, differences over the interpretation or application of ba sic agreements are arising continually. They are usually handled informally at first, the complaints being simply to the effect that one party or the other is not observing the agreement in some particular. Typically they involve one employee or a small group; they relate, usually, to a specific managerial or employee practice. The interest of both employer and employee in such disputes is generally best served by a quick determination of the issue, since ordinarily there is little at stake. Confusion and uncertainty arising from a delayed settlement of the meaning of an agreement might very easily do more harm than a quick decision which fails of perfect justice or accuracy.

The term "labor dispute" has been used above to apply only to controversies which find more or less formal expression. But there is a latent controversy which must be recognized. Employees who are afraid to protest against wages or working conditions, or who have learned through experience the futility or danger of protesting, may be nevertheless in disagreement with their employer. It is characteristic of non-union establishments that employee dissatisfaction finds no real expression, and is ignored or suppressed by the management; the smouldering discontent in such plants is not only a threat to "industrial peace", but it also interferes with efficient operation. If peaceful methods of settling labor disputes are ever to prevail, some way will have to be found to permit free expression and adjustment of employee complaints in establishments where they are now smothered. It may be possible to conceal employee discontent and postpone adjustment of grievances by preventing or suppressing genuine labor organization. But such postponement only adds to the dynamite accumulating for the ultimate explosion; it is not a settlement of the questions inherent in employer-employee relationships.

\section{Methods of Settling Labor Disputes}

Labor disputes are carried on, and eventually ended, in one of three different ways, or a combination of them. These different processes. which are at once ways of disputing and ways of reaching a settlement are (I) by direct negotiation, (2) by direct action, and (3) by mediation and arbitration. Governmental intervention sometimes settles labor controversies by direct statutory action, as, e. g., the Adamson Act, ${ }^{5}$ which established an eight-hour day for railroad employees, or by securing an injunction against the railway shop employees, as was done in I922. The normal handling of labor disputes, however, begins with conferences between the parties, and where the question is not disposed of in conference, direct action or handling through mediation and arbitration normally follows. Arbitration as a

5. 39 STAT. 72ז (I916), 45 U. S. C. A. §65 (1928). 
method of settling labor disputes can be evaluated only against the whole background of its alternative or supplementary processes.

By far the greater number of disputes arising in union establishments are adjusted by direct negotiations between the union and the employer. Every labor organization handles a steady stream of employee complaints, and all but a small proportion of them are settled quickly with the immediate supervisor of the person complaining. Of those which are not settled "on the ground", the greater part are agreed upon between higher officials of the union and the management. Negotiation is less successful in handling major disputes arising out of requests for changes in basic wages or working conditions, but even there most controversies are settled by agreement directly between the parties.

Direct negotiation is by all odds the most satisfactory method of settling labor disputes. The face-to-face contact of employers and union representatives, while at first it may cause distrust because of superficial differences in conduct, ultimately makes for mutual understanding. Each side comes to know the problems of the other, and to think of their differences in terms of their common interests. Management representatives come to understand the reality and the strength of employee dissatisfaction; union representatives come to realize the limitations imposed upon management by business conditions and by boards of directors. Personal friendliness develops without any sacrifice of the interests of the parties represented, and in such an atmosphere each side will do everything possible to settle the dispute with the minimum of hardship to the other. As has been said, union proposals very frequently include a request for an extension of employee control over working conditions, or rather an extension of the area of joint control. Where the habit of discussing and deciding controversies has been well developed, union representatives are better able to participate in joint supervision of working conditions-and management officials are much more inclined to accept such union participation. The process of direct negotiation is not only highly successful in settling controversies, but it is also creating other values of the greatest social significance by its development of good will and cooperative activity between employer and employee.

Direct negotiation, however, is not always successful. The interests or demands of the board of directors cannot always be reconciled with the interests or demands of the union membership; sometimes it is impossible to find a satisfactory basis for compromise. Where direct negotiation upon a dispute fails to bring settlement, or when there is no established procedure for carrying on such negotiations, the employer or the workers may proceed to "direct action".

Here, too, we need a broader conception of the nature of industrial conflict. The employees, through their union, have two main types of direct 
action-the strike and the boycott. The employer, because of his position at the head of his establishment, has not only the power to lock out all union members, but he has also the power to put into effect his decision. A union, askinig for higher wages, and denied the increase by the employer, cannot simply write out increased pay checks; but the employer, asking for a wage cut and unable to secure union consent, can instruct the timekeeper to put the reduction into effect. The union, asking for reinstatement of an employee it considers unjustly discharged, cannot arbitrarily put him back on the payroll; the employer, however, can stop the pay of any employee he wants to discharge, even though the union does not agree that the discharge is justified. Where the employer takes action, after final disagreement with the union, the organization has only one recourse-the strike. In principle, the action of an employer in putting a decision into effect over the protest of his employees is as much "direct action" and open conflict as is the strike. Because wage cuts or other employer action may be made quietly at a time when the workers are unable to strike, this type of industrial warfare escapes public attention; but when industrial or other controlling conditions change, and the workers are again able to strike effectively, the resulting conflicts are more bitter, more prolonged, and more destructive because of the arbitrary action of the employer taken when the workers were defenseless. Direct action by one side or the other, especially if it takes the form of a strike, is the most spectacular method of settling labor disputes, but it is also the least satisfactory. Where dependence is placed upon direct action, the tendency is for settlements to be extreme in their provisions; in times of prosperity, or labor shortage, or other condition making the employer relatively unable to resist union pressure, strikes or threats of strike can win concessions not justified by other factors. On the other hand, in time of depression, or seasonal unemployment, or in the absence of organization, the employer can force wage reductions or delay justified increases, and can put into effect working conditions below standard. Drastic action by either party in such situations tends to create in the other a desire for retaliation, just as overwhelming victory in international warfare usually leads to unjust peace terms and a later war of "revenge". Apart, therefore, from all considerations of the cost and public inconvenience of strikes or lockouts, the use of arbitrary power by either employer or union unsettles industry and is dangerous to everyone concerned.

\section{Definition and History of Industrial Arbitration}

The variety of definitions of arbitration indicate the difficulty of saying precisely what arbitration is, in the industrial field. ${ }^{6}$ Employer and employee

6. For definitions of arbitration in labor disputes see 29 Monthly LABor REv. (U. S. Dept. of Labor, Nov. I929) I4; I7 REPORT OF INDUSTRIAI CoMcaission (I900) lxxv; BLUM, LABOR ECONOMICS (1925) 239. 
attitudes differ greatly from industry to industry; the length of experience with collective bargaining varies widely; the public interest in labor controversies varies from time to time, and from industry to industry. These and other factors have been reflected in the forms set up in experiments with arbitration machinery, and it is no easy task to decide what is the essence of arbitration. No definition can include all the variants.

Arbitration, it may be said, is the reference of a dispute to some tribunal outside of the parties immediately interested, for a decision which will in fact be binding. Not all arbitration is by third parties; not all arbitration is undertaken by joint action; not all arbitration decisions are accepted in advance; and, finally, not all arbitrations involve issues upon which the parties are in disagreement. Arbitration boards frequently function as mediators, or conciliators; mediators and conciliators frequently function as arbitrators. Arbitration boards, given a specific dispute to decide, may evade direct decision but lay down a rule, susceptible of definite application, which will settle the controversy. Disputes in which one or both parties must escape the responsibility for decision, although both are agreed upon what the decision should be, are not infrequently referred to and "decided" by arbitration boards. The composition and operation of industrial arbitration boards include adaptations to every variant among the disputes they handle.

This broad definition of arbitration includes many types of settlement not usually thought of as coming within the meaning of the word. But the essence of all such settlements is the same. The dispute is taken away from those too closely concerned in its early handling. It is investigated by persons not to be immediately affected by the terms of its settlement, and only indirectly if at all responsible to the employees and management officials involved in the controversy. These new persons, primarily interested in finding a basis upon which a workable adjustment can be made, have sufficient prestige, influence, or power to make their decisions practically effective. Arbitration as it has developed in the labor field is a combination of these elements.

Illustrations of these variations will bring out the point more clearly. The first arbitration board under the Hart, Schaffner \& Marx agreement, in I9I I, functioned successfully through a very difficult period with one representative each from the union and the company, and no "neutrals"." The national agreement between the International Typographical Union and the American Newspaper Publishers' Association provides for arbitrations by two-party boards, ${ }^{8}$ with the provision that a third party may be called in if the two-party board is unsuccessful. Railway labor disputes may be handled by the United States Mediation Board, and by a Presidential Emergency

7. Clothing Workers of Chicago (Amalgamated Clothing Workers, 1922) 50.

8. Tracy, History of the Typographical Union (Igr3) 647. See also Low, Civic Federation and Industrial Peace (Nov. I9I2) 44 ANNals 13. 
Board, under the Railway Labor Act, ${ }^{9}$ without the request of both partieseven without the request of either party. ${ }^{10}$ The Joint Bureau of Standards in the Cleveland Ladies' Garment industry fixed piece rates by time-studies of the disputed operations. ${ }^{11}$ The decisions of the United States Railroad Labor Board were rarely accepted in advance, and the Transportation Act ${ }^{12}$ under which the Board functioned did not make its decisions binding; nevertheless, very few of the 4000 decisions of the Board were not put into effect (those few, however, being among the most important ${ }^{13}$ ).

All of these processes are arbitration, and the term should be understood in a sense broad enough to comprehend them all.

\section{History}

The reference of disputes to arbitration appears fairly early in American Labor history, but most of its significant development has been since 1900 . Arbitration of a dispute involving iron puddlers in Pittsburgh, in 1865 , is reported by the Bureau of Labor Statistics. ${ }^{14}$ Shoe workers of Lynn, Mass., are reported to have arbitrated a dispute in I870. ${ }^{15}$ Between I880 and I89o bricklayers in New York, Boston, and Chicago entered into arbitration agreements with the associations of their employers, which agreements functioned very well until 1900. ${ }^{16}$ The Amalgamated Association of Street and Electric Railway Employees already had its present arbitration policy well developed, ${ }^{17}$ and local unions of several other internationals had by Igoo secured agreements providing for some sort of arbitration of disputes arising during their continuance.

Three groups of workers are of outstanding importance in the development of arbitration since rgoo-those in the printing trades, the needle trades, and the railway industry. Passage of the Erdman Act, ${ }^{18}$ in June, I898, marks the real beginning of arbitration in the railway industry ${ }^{10}$ action taken by the International Typographical Union, in its I900 convention, led to the conclusion of an arbitration agreement in IgoI between the union and the American Newspaper Publishers' Association which in its essentials is still in effect; ${ }^{20}$ and the strike of clothing workers in the Hart,

9. 44 STAT. 577 (1926), 45 U. S. C. A. \& r5I (Supp. 1933).

I0. RaIlWay LaboR ACT, 44 Stat. 582, §6, 586, § 10 (I926), 45 U. S. C. A. $\$ \S 156,160$ (Supp. I933).

II. LEVINE, Women's Garment Workers (Ig24) 370.

12. 4I STAT. 456 (I920), 45 U. S. C. A. \$ I3I (IQ28).

I3. Including the decisions reducing the rates of shop employees, in I922 (3 R. L. B. 423, Decision ro36) and the series relating to the choice of employee representatives on the Pennsylvania Railroad (2 R. L. B. 207-223, Decisions 218, 219, 220).

14. 29 Monthly Labor Rev. (U. S. Dept. of Labor, Nov. I929) I6.

I5. I7 REPORT OF INDUSTRIAL CoMmission (IgOI) 406.

I6. Id. at 376 et seq.

17. Id. at 419,420 .

18. 30 STAT. 424 (1898), 45 U. S. C. A. \$ IOI (1928).

19. Chambers, Achievements of Federal Mediation (1918) 7 Acad. of PoL. Scr. Proc.,

N. Y. C. 3-5.

20. Tracy, History of the Typographical Union (19I3) 645-65I. 
Schaffner \& Marx factory in Chicago, in I9Io, led to the signing of an arbitration agreement covering that establishment, ${ }^{21}$ beginning the now extensive use of arbitration for settling disputes in the needle trades. Many local unions in other industries provide for arbitration of controversies arising out of interpretation or application of basic agreements, but the development has been more consistent, and more the object of definitely formulated union and management policy, in these three industries than in any others.

A very incomplete tabulation of arbitration decisions in the United States, made by the Bureau of Labor Statistics, lists 54 decisions as having been made from 1865 to 1914,98 decisions from 1915 to I920, and $27 \mathrm{I}$ from I92I to I929. ${ }^{22}$ The purpose of the Bureau's study was such as to exclude many decisions, and only a fraction of arbitration awards handed down have been reported to the federal government. But the increase is not overstated by the figures given. In the railway industry, from 1898 to I9I 3 there were 12 arbitration decisions in labor disputes; ${ }^{23}$ from 1927 to 1933, inclusive, there were 64 arbitration decisions (excluding those involving only grievances). ${ }^{24}$ Twenty-seven major disputes on the railways were submitted to arbitration in the one year 1927, twice as many as in the entire fifteen-year period I898-I9I3.

With the adoption of the National Industrial Recovery Act, in I933, the problem of settling labor disputes entered into a wholly new phase. It is still too early to decide what will come from the famous Section $7 \mathrm{a}$, but the confusion that has attended attempts to enforce its provisions indicates that the law needs clarification, and that the machinery for administering it is not suited to the job.

\section{Bases of Arbitration}

Arbitration of labor disputes in the United States, before the passage of the N. I. R. A., was principally a result of agreements between employers and labor unions. Attempts at compulsory arbitration had failed, ${ }^{25}$ and the conciliation work of state and federal labor departments was far from perfectly effective. Even the Railway Labor Act of 1926, under which railway labor controversies were being arbitrated, was more of an agreement between managements and unions than imposed federal regulation. ${ }^{26}$

Submission of disputes to arbitration was for the most part voluntary. The United States Board of Mediation had and has the power, as the Rail-

2I. Clothing Workers of Chicago (Amalgamated Clothing Workers, I922) 49.

22. 29 Monthly Labor Rev. (U. S. Dept. of Labor, Nov. Ig29) I5.

23. Chambers, loc. cit. supra note 15.

24. U. S. Board of Mediation, AnNual Rep. (I933) 7.

25. The Kansas Industrial Relations Court Law was declared unconstitutional, insofar as it made arbitration compulsory. Wolff Packing Co. v. Court of Industrial Relations, $262 \mathrm{U}$. S. 522 (I923).

26. See reports of House and Senate Committees; H. R. REP. No. 328, 69th Cong., Ist Sess., Ser. No. 9463 (I926) ; SEN. REP. No. 222, 69th Cong., Ist Sess., Ser. No. 2306 (I926). 
road Labor Board had had under the Transportation Act of I920, to intervene in labor disputes uninvited. Its intervention, upon its own initiative or upon the request of either party, postpones direct action until attempts to settli disputes by mediation have failed, and the parties refuse to arbitrate. Even at this stage in the dispute, direct action may be further delayed by appointment of a Presidential Emergency Board, under the law, to investigate and report upon the controversy. The Board must report within thirty days of its appointment. Neither party may move in the dispute until thirty days after the report of the Emergency Board; but thereafter there is no compulsion exercised under the law. In theory, the acceptance of the results of this process of investigation, mediation, and arbitration is voluntary; in practice, the delay, and the weight of recommendations by the United States Board of Mediation, or by a Presidential Emergency Board, make labor acceptance almost compulsory. Railway managements are under somewhat less pressure, apparently, to accept the arbitration services of the Board of Mediation, or to follow the recommendations of Presidential Emergency Boards.

Aside from the railway industry, arbitration agreements or settlements in the United States were wholly voluntary. Each side, it is true, usually acted with a healthy respect for the bargaining power of the other, and in the belief that settlements secured through arbitration would in the long run be as satisfactory as those gained by direct action. There was, too, a realization that both management and union lost in public esteem through their failures to compose their differences amicably. The terms of arbitration agreements, and the decision to enter into them, were made by the parties without legal compulsion. But awards of arbitration boards were final and binding, unless provision was made for appeal to another board for review.

\section{Arbitration Machinery}

Several types of arbitration machinery have been created by agreement or by law in the United States. The machinery set up has recognized the distinction in forms of disputes, noted above; there are boards for handling complaints or grievances, and separate boards for the arbitration of major disputes. Agreements between the International Typographical Union and the local and national associations of newspaper publishers provide for three kinds of arbitration boards-one local board for complaints and grievances; a local board for wage and rules decisions; and a national board for review of local wage and rules decisions on appeal. The national board also handles certain questions, such as that of appointing impartial chairmen, upon which the local boards cannot agree. The Amalgamated Clothing Workers' agreement with Chicago manufacturers establishes a Trade Board, to handle grievances and complaints, and an Arbitration Board to hear appeals from 
the Trade Board decision, and to decide general wage and rules questions arising during the life of the agreement. Under the Railway Labor Act, as amended in $1934,{ }^{27}$ a national board of adjustment is created to hear and decide disputes growing out of interpretation and application of basic agreements; decision of this board is final and binding. Separate provision is made for arbitration boards to handle disputes growing out of proposals for basic changes in wages or rules.

Not all arbitration machinery is classifiable under the heading of arbitration boards. The existence of an arbitration board, and the creation of precedents by its decisions, speedily gives to mediation and conciliation processes most of the characteristics of arbitration. Deputies subordinate to the Trade Board under the agreements of the Amalgamated Clothing Workers in Chicago, and mediators on the staff of the United States Mediation Board, for example, are familiar with the standard decisions on questions which have been handled through arbitration. Functions of persons such as these make them a part of the arbitration machinery, and frequently short cut the arbitration process. Disputes may be withdrawn or settled upon information or advice of mediators; of 2 II 3 cases submitted to the United States Board of Mediation from I927 to I933, 645 were settled in mediation, 549 were withdrawn, and 269 were settled by arbitration. ${ }^{28}$ Disposition of the first two groups was certainly largely determined by what had happened in earlier arbitrations of similar disputes. The mediator is properly a part of arbitration machinery in another sense; he does precisely what a good board of arbitration does in most of the disputes submitted. In explaining the position of each party to the other, in trying to find a middle ground, in urging agreement on a reasonable compromise, the mediator and the arbitrator perform the same function.

Another function of the United States Mediation Board, and of other governmental agencies since 1933 , is in the nature of arbitration. Among the most difficult labor disputes to settle are those arising out of the demand for union recognition. Employers are usually of the opinion-or profess to be-that there is no desire among their employees for collective bargaining, or for representation by an "outside" union. If the employees, through some one who claims the right to speak for them, ask for changes in wages or working conditions, and the employer refuses to meet with the representative of the employees, there is little basis for negotiation or arbitration. Direct action, by. employer or employees or both, follows quickly-and the fighting in such disputes is frequently violent.

In the effort to find a peaceful settlement for disputes over union recognition, the Railroad Labor Board worked out a method of submitting the question to the employees by secret ballot. The Board of Mediation devel-

27. P. L. No. 442,73 d Cong., Ist Sess. (1934).

28. U. S. Bd. of MEDIation, ANNUAL Rep. (I933) 6. 
oped this technique, and under the Railway Labor Act as now amended some such method for determining employee representation is almost compulsory in disputes over union recognition. ${ }^{29}$ The dispute then centers about the rulec relative to balloting; such questions as the list of properly eligible voters, the methods for guaranteeing secrecy, the counting of the ballots, etc., must be decided. The Board of Mediation has the power, if the parties cannot agree, to fix election rules for these employee ballots.

This process, which involves the reference of a dispute to some objective standard for settlement, is not different from the use of such standards by arbitration boards in other disputes. Changes in living costs, wages of employees not involved in the dispute under consideration, time-studies of operations, etc., have often been used as the criteria for settlements, in lieu of a direct decision by the arbitrators. Employee balloting on union recognition is of this same nature, and is a special case of arbitration.

Use of this method of determining employee representation involves the acceptance of two principles, first that the employees have a right to bargain collectively if they desire, and second that they have a right to bargain through whatever representative or other method they may choose. By grounding public policy upon adoption of these two principles, a way has been found for peaceful settlement of the most difficult and most dangerous type of labor disputes.

\section{Composition of Arbitration Boards}

Arbitration boards established by agreements or by law vary in size, but always have equal representation of employer and employees. Trade Boards in the Chicago clothing industry had at first II, and later 5 representatives each of union and management; $;^{30}$ joint committees for handling grievances in the Typographical Union agreements with newspaper publishers consist of two representatives of each party; boards of adjustment in the railway industry had no fixed number, under the original Railway Labor Act, and under the law as now amended the national board has 18 (divided into four sections of $5,5,5$, and 3 ) representatives for each group. ${ }^{31}$ Arbitration boards for handling wage and rule changes usually have one representative of each party, although the Railway Labor Act provides two representatives where that is preferred. Boards handling grievances usually try to arrive at decisions without calling on a neutral party; where a decision cannot be reached in that manner, the neutral member of the board serves as chairman. Under the Railway Labor Act, boards may consist of three or six members, and the larger boards have two neutral arbitrators. ${ }^{32}$

29. RaIlway Labor Act, P. L. No. 442, 73d Cong., Ist Sess. (1934) §2.

30. Clothing Workers of Chicago (Amalgamated Clothing Workers, 1922) $55,57$.

3I. RaIlWAy LabOR ACT, P. L. No. 442, 73d Cong., 1st Sess. (1934) § 3.

32. There have been several deadlock decisions in six-member boards. One of these was a wage case involving one class of train service employees throughout the west. In such deadlocks, unless later sessions of the board of arbitration result in settlement, the members simply agree to disagree, and the dispute is left unsettled. 


\section{Choice of Board Members}

Each party to a labor dispute selects its own representatives upon the arbitration board. In handling grievances, these members are usually union and management officials. For arbitration boards handling wage and rules questions, or appeals from local and grievance boards, outsiders sometimes represent union or management. Thus $\mathrm{Mr}$. Clarence Darrow represented the Amalgamated Clothing Workers (then the United Garment Workers) in their first arbitration proceedings under the Hart, Schaffner \& Marx agreement. Former Secretary of Labor William B. Wilson represented the Brotherhood of Railway Clerks in an arbitration with the New York Central Railway, in I926. The Board of Referees, which arbitrated disputes in the Cleveland ladies garment industry in I9I9 and thereafter, was composed of three men, none of whom represented either employer or union. These, however, are exceptions; the general rule is that the union is represented by some one of its own officers on boards of arbitration, and the management by someone from its personnel staff.

Choice of impartial members is of course the big problem in the formation of arbitration boards. Arbitration agreements sometimes name the impartial member of the boards; sometimes government officials are asked to choose neutrals; the most common arrangement, however, is for the partisan members first to try to agree upon an impartial chairman. If that is not possible, selection of the chairman may be left to a higher arbitration board (as in the International Typographical Union agreements referred to above) or to public officials. Under the Railway Labor Act, the Mediation Board appoints neutral members of arbitration boards when the parties are unable to agree.

Arbitration succeeds or fails with the choice of impartial members of boards. The history of arbitration agreements discloses many instances where the entire idea was discredited because of improper conduct by the neutral arbitrator. ${ }^{33}$ But it is not simply in showing partiality that the "third party" can bring about the failure of arbitration. Many arbitrators enter upon their duties with the high-minded belief that they know better than either union or management exactly what the situation requires. A few, a very few, may actually have a better understanding of the dispute than do the people involved; even among these few it is rare that a neutral can put across his conception in a way to avoid antagonism from one or both sides. Where the neutral member understands that he is only a special kind of mediator, and that his job will be best done if he lays a basis for handling disputes which will make his services unnecessary in the future, his chances of satisfying everyone concerned are much greater. It is true, however, that many disputes simply cannot be compromised or mediated; the arbitrator

33. For an example, see Tracy, History of the Typographical Union (IgI3) 738-744. 
frequently must take a stand with one or the other party. For such a situation the neutral man must have some strength of character; there are sometimes very stormy scenes at the executive sessions of arbitration boards. The arbituator who yields to blustering or who weakens after he has made a decision not only ends his own usefulness but also causes distrust of the whole arbitration process.

Direct political appointment of arbitrators, or the use of men holding political office to arbitrate disputes not involving public employees, has proven to be a mistake. The Railroad Labor Board, all of its members appointed by the President of the United States, might have been much more successful if its personnel had been differently selected. Public utility commissions, acting as labor arbitrators, leave a great deal to be desired. On the other hand, appointees of the United States Board of Mediation have been very successful in handling railway labor disputes, and with one exception there has been no serious charge of bias or partiality. The Board, although politically appointed, has been non-political in its appointments; the men selected for arbitrators have included federal, state, and local judges, economists, statisticians, etc.

\section{Procedure in Arbitration}

Hearings before labor arbitration boards are usually very informal. Representatives of both sides appearing before the board are allowed the widest latitude in the evidence or arguments introduced, and the manner of presentation. Regulations governing procedure are only general in most arbitration agreements, but in others-notably those of the typographical union-detailed provisions are made for arbitration board hearings.

Procedure under the Railway Labor Act is more formal than those under trade agreements. Opening statements by each side outline the issues and the evidence to be introduced; witnesses are sworn, and examined and cross-examined in something approaching court-room style. The petitioner opens and closes, in both evidence and argument. Awards of the arbitration boards are filed with the clerk of the federal court in the district where the hearings are held. Any award can be impeached, on grounds enumerated in the law; unless petition for impeachment is filed within ten days after the award is handed down, the law provides that "the court shall enter judgment on the award, which judgment shall be final and conclusive on the parties".

\section{Willingness to Arbitrate}

Arbitration in the United States is voluntary, except in the handling of grievance disputes in the railway industry. In considering submission of disputes to arbitration, the parties are influenced by many factors. Relative bargaining power of the employer and the union, for example, will affect the readiness of one or the other to agree to arbitration. Business conditions, 
directly as well as in their bearing upon relative bargaining power, make the parties to a dispute willing or unwilling to arbitrate. The psychology of workers or employers, their mutual confidence or distrust, the relation of either group or of the industry to the "public"-all affect the readiness of the parties to permit an "outsider" to decide their controversies.

An illustration of the effect of business conditions and relative bargaining power upon arbitration is provided in the history of the Railway Labor Act since its passage. The United States Board of Mediation, immediately after its creation in 1926, received for handling a large number of disputes which had accumulated or had been pending with the former Railroad Labor Board, and has been receiving for mediation most of the disputes which could not be settled by direct negotiation since that time. In the following table, taken from the annual report of the United States Board of Mediation for the fiscal year $\mathrm{I} 933,{ }^{34}$ " CC" refers to major disputes, "GC" to grievance cases.

\begin{tabular}{|c|c|c|c|c|c|c|c|c|c|}
\hline \multirow[b]{3}{*}{ Year } & \multirow{2}{*}{\multicolumn{3}{|c|}{$\begin{array}{l}\text { On Fand and } \\
\text { Received }\end{array}$}} & \multirow{2}{*}{\multicolumn{2}{|c|}{$\begin{array}{l}\text { NUMBER of CASES } \\
\text { Cases Settled (Total) }\end{array}$}} & \multirow{3}{*}{$\begin{array}{l}\text { With- } \\
\text { drawn }\end{array}$} & \multirow{2}{*}{\multicolumn{3}{|c|}{ Closed, Refusal }} \\
\hline & & & & & & & & & \\
\hline & C & GC & Total & Mediation & Arbitration & & C & GC & Total \\
\hline I927 & 265 & 7 & 272 & 57 & 27 & 24 & 0 & 0 & 0 \\
\hline 1928 & $25^{2}$ & $3^{2}$ & 284 & 84 & I4 & 45 & $\mathrm{o}$ & $\mathrm{o}$ & o \\
\hline I929 & 172 & 69 & $24 \mathrm{I}$ & 64 & Io & 62 & 9 & 0 & 9 \\
\hline I930 & I 55 & 250 & 405 & 73 & I2 & 86 & 3 & 0 & 3 \\
\hline I93I & I II & 428 & 599 & 98 & II $5^{*}$ & $8 \mathrm{I}$ & I & o & I \\
\hline 1932 & 228 & $46 I$ & 689 & I39 & $5^{I}$ & I 28 & 47 & 33 & 80 \\
\hline I933 & I75 & $62 \mathrm{r}$ & 796 & I30 & 40 & I23 & 39 & 96 & I35 \\
\hline
\end{tabular}

* II3 of this total were grievances, and of them more than 80 were in one group of disputes submitted by the Brotherhood of Railway Clerks and the Railway Express Agency.

The effect of the depression was, first, to increase the number of disputes to reach the Board of Mediation-indicating not only an increase in. disputes originating, but also the decreasing effectiveness of direct negotiation. The increase in disputes was especially marked in grievance cases, of which I02 were received by the Board in 1929, and 507 in 1933. A second effect of the depression was delay in securing settlements of disputes. A third effect was that the proportion settled by mediation and arbitration decreased. Finally, the refusal of the parties (here, as a matter of fact, the railroad managements) to arbitrate labor disputes became very marked in I932 and I933.

Accumulation of unsettled grievances caused a very acute situation to develop in railway labor relations in I933 and I934. One large railroad was threatened with a general strike of all its employees if it did not adjust outstanding grievances. As a result of the condition that had developed, the unions in 1934 asked Congress to amend the law to improve the machinery

34. U. S. Bd. of Mediation, Annuar Rep. (I933) 6. 
for the settlement of grievances growing out of the application or interpretation of basic wage and rules agreements. After a vigorous campaign, carried right up to the closing minutes of the last session of Congress, the rail:: ay unions succeeded in having the Railway Labor Act modified to make arbitration of grievance disputes (by a National Board of Adjustment if other machinery was not voluntarily set up by the parties) virtually compulsory.

\section{Success of Arbitration}

Arbitration, as a means of settling labor disputes, has to meet several tests. First, does it prevent open labor conflict? Second, does it secure reasonably fair settlements? Third, does it make for better relations in industry by preserving direct negotiation? Fourth, can it be developed to handle all types of disputes?

\section{Strike Prevention}

Arbitration of labor disputes has not always prevented strikes. There have been strikes, like that of the railway shop crafts in I922, against awards of arbitrators. Sympathy strikes have been called by unions having arbitration agreements. Outlaw strikes sometimes follow unpopular arbitration awards. It is true, also, that employers sometimes fail to live up to the terms of arbitration agreements, and fail to put into effect decisions they had agreed to accept.

But a consideration of conditions in the industries where disputes are now regularly arbitrated cannot fail to bring conviction that in the arbitration process we have the answer to the problem of strike prevention. The stormy history of the needle trades, in all centers where arbitration agreements are in effect, has given way to a peaceful and orderly settlement of disputes. That this is not due to a change in the industry, nor in the attitude of the workers, is proven by the strikes that still occur where arbitration agreements are not in effect. One of the most vigorously contested strikes in the history of the men's clothing industry took place in I925 when a large clothing concern, with factories in Chicago and New York, decided not to renew its agreement with the Amalgamated Clothing Workers; in other markets, where the employees have been unorganized or are not covered by arbitration agreements, there have been strikes with all the characteristics of the early battles in the industry. The railroad industry, which saw many serious strikes under the imperfect labor provisions of the Transportation Act between I920 and I922, under the Railway Labor Act weathered the depression and the first major controversy of the recovery period without one stoppage. Arbitration, although weakened by management attitude during the depression, is firmly established upon the railroads. The International Typographical Union, in its strike to enforce the forty-four-hour agreement in its trade, showed that the peace which had existed with so few breaches between 
the union and employing printers was not due to the weakness of the organization. The Amalgamated Association of Street and Electric Railway Employees can and does strike where arbitration agreements are not in effect. Open industrial conflict in these industries shows that the peace which has been secured in certain areas or during certain periods must be attributed to the development of the arbitration process.

\section{Arbitration Settlements}

On the whole, arbitration settlements have been satisfactory to everyone concerned. Individual decisions have caused strong protest, and the attitudes of some arbitrators have been difficult to understand. Sometimes neither side is satisfied with arbitration decisions, and the writer has known of instances where the indicated decision of the neutral arbitrator was so far out of line with the necessities of the situation that employer and union agreed, at the last moment, upon a settlement and a withdrawal of the dispute from arbitration. Generally, however, arbitration decisions are acceptable to both sides.

Very few extreme settlements are made by arbitration boards. The temporary factors which make other types of settlement so frequently reflect sudden changes in bargaining power have much less effect upon arbitration decisions. Standards capable of application under changing conditions come to be recognized; changes in wages and working conditions are slower, and consequently less responsive to local or temporary changes. These and other elements in arbitration tend to bring small and continuous adjustments rather than the large pendulum swings of industries where bargaining power alone determines the settlement of labor disputes.

The long time history of wages in industries covered by arbitration agreements shows that rates of pay rise by about the same amount as they do in union establishments where wages are determined primarily with reference to the possibility of a successful strike. As would be expected, wages rise more slowly and not nearly so far during periods of increasing business activity, where arbitration is the rule; but during depression, the wage decline is later and less under arbitration than where direct bargaining power determines settlements.

But in the extension of union power over employment conditions there is no comparison whatever between direct bargaining, with the strike or lockout threat in the offing, and the arbitration process. The establishment or extension of a principle of union participation in personnel management comes naturally, in arbitration, because the neutral arbitrator can see the abstract and long time questions involved. Concessions wrung by the victor from the loser after an open conflict are never secure; they may be, and frequently are, lost in the next reversal of business conditions. Where 
decisions are made by arbitration, however, it is almost inevitable that the union should be given a steadily larger share in the responsibility for labor management, with corresponding limitations upon the power of the employer. The $\epsilon_{2}$ is rarely any reversal of this tendency, and the arbitration process is in fact building a more and more complete industrial democracy.

Union officials sometimes dislike the increased responsibility which comes to them with their increased power. Many of them would prefer arbitration decisions to be flat mandates, rather than-as they frequently are-merely bases upon which the parties must cooperate for future handling of the problem under consideration. But with responsibility labor organizations are gaining in stability. The demagogue type of leader, who comes to the fore in strike situations, gives way to the more intelligent and responsible labor leader when the union is forced to share responsibility for basic labor decisions.

Settlement of disputes by arbitration, it may be said, leads to a stabilization of wage changes, and to the steady extension of union responsibility in industry. Settlements by strike, or under threat of strike, lockout, or other direct action, are more extreme and more fluctuating, both as to wage rates and as to union control of working conditions.

\section{Arbitration and Direct Negotiation}

As has been pointed out above, the direct settlement of labor controversies is from every point of view the best method. But direct negotiation is always carried on with an eye to the alternatives; it will be successful in settling controversies only when both sides prefer not to handle them by other available methods. Employer and union alike, therefore, can be considered as approaching any important dispute with an estimate in mind of the advantages and disadvantages of settling in conference.

The arbitration process tends to give to each side in direct negotiation a fairly definite basis for making such an estimate. The delays, the cost, and to some degree the probable decision upon the dispute can be judged fairly well. Each side knows that the other will have little difficulty in submitting the dispute to arbitration, if agreement cannot be reached. Even though convinced of the justice of their own position, both sides know that they may not be able to explain to an arbitrator, or to convince him. The tendency to find a compromise, somewhere near the probable decision of the impartial arbitrator, becomes steadily stronger.

Where the alternative to a negotiated settlement is the strike or lockout, the atmosphere of the conference is very different. If one side or the other cannot stand an open conflict, the negotiated settlement becomes as unfair as the result of direct action would be. When each side feels it can win, the negotiations often become nothing more than ultimatums. When one party 
or the other is definitely in a stronger fighting position, and tries to dictate a settlement, the weaker party sometimes resorts to direct action in despair. It is true, of course, that if employer and union were equally well informed, and were each able to judge the other's attitude accurately, conferences even where the only alternative was the strike or lockout might bring just and speedy settlement. A few strikes, too, bring to each party a healthy respect for the power of the other, and a reluctance to break off relations without real justification. But on the whole, negotiated settlements where the strike or the lockout is the alternative reflect the anticipated result of open conflict.

Direct negotiation, therefore, is carried on in a much better atmosphere, and with much better prospect of a quick and equitable settlement of the issues involved, where there is provision for arbitration by a neutral person. Principles become settled, and clearly defined; the penalty or the discontent attending delay puts a premium upon immediate adjustment. The arbitration machinery is needed less and less frequently, usually only for the handling of major questions or the application of basic principles to entirely new situations. Provision for the voluntary arbitration of labor disputes tends to strengthen and extend the process of settlement by direct negotiation.

\section{Adaptability of Arbitration}

The types of disputes which have been submitted to and settled by arbitration have been of almost every conceivable kind. Arbitration is usually thought of as being best suited to controversies involving determinations of facts, where settlement depends upon measurement or upon compromise based on quantitative data. Standard wage disputes are more or less of that description, but the more significant though less well known arbitration decisions in labor disputes have dealt with very different controversies.

Among the questions which have been submitted to arbitration have been those dealing with the displacement of labor by machinery. What protection, if any, does an employer owe to his employees when he introduces a machine which will put some of them out of work? Unemployment reserves, and employment guarantees, have been passed upon in arbitration decisions. The complex problem of union status-beginning with recognition, and proceeding through union preference to the closed union shophas all gone through the arbitration process. Disputes between company unions and legitimate unions over employee representation have been decided through the arbitration machinery of the Railway Labor Act. The right of the employees to share in the control of casual or part time employment has been recognized in arbitrations; the right of the employer to contract out work covered by union agreement has been narrowly restricted by arbitration decisions. 
Jurisdictional questions, certainly not the least troublesome of labor disputes, have several times been arbitrated in the railway industry. Reductions in employment have led to combining of different kinds of duties on mary positions, and the question of union jurisdiction has naturally arisen. In one such case, which was in form a dispute between a railway union and the management, there appeared as aids to the management not only the officers of another carrier, but also the officials of the other labor union involved in the question. It is notoriously difficult to secure arbitration of jurisdictional disputes between the labor organizations affected, but the arbitration process has been able to surmount this difficulty by handling the dispute as between the employer and one of the employee groups involved. The other employee groups, of course, are not bound by such a decision, but where their recourse is to arbitrate with the employer the probability is that the decision of the first arbitration board will have great weight in succeeding cases.

Adaptation of arbitration machinery to various kinds of disputes has already been mentioned; the troublesome question of union recognition is handled through secret balloting of the employees, the daily complaints and grievances of employees are handled by special boards-trade boards, boards of adjustment, etc.-designed to get just and speedy decision.

\section{Conclusion}

Arbitration has come to be very widely used in the settlement of labor disputes. The result has been not only to reduce the danger of strikes and lockouts, but also to secure equitable adjustment of labor relationships. Agreements are interpreted, and their principles extended and developed, in a way that secures stability in industry and an even development of the processes of collective bargaining. To encourage the peaceful settlement of disputes by arbitration, there must be a frank recognition throughout industry of the right of workers to organize, to bargain collectively, and to choose their own representatives for bargaining free from all interference or influence of their employer.

Government assistance in the development of arbitration can be carried too far. Compulsory arbitration, with its implication of direct political appointment of arbitrators, would do more to defeat than to aid in peaceful settlement of labor disputes, unless limited to minor controversies. Given proper encouragement by the public and by state and federal governments, arbitration can be adapted to handle every type of labor dispute; it will result in steady improvement in employer and employee organizations, and in greater recognition of their responsibility to each other, to industry, and to the community. 